\title{
Assessment of the status of soil organic carbon stocks under natural forest and plantation ecosystems in southern Karnataka, India
}

\author{
Pradeep, K.S. Anil Kumar', * R.K. Avinash and K.S. Karthika ${ }^{1}$ \\ University of Agricultural Sciences, GKVK, Bengaluru-560065, Karnataka, India \\ ${ }^{1}$ ICAR-National Bureau of Soil Survey and Land Use Planning, Hebbal, Bengaluru -560024, Karnataka, India
}

(Manuscript Received: 12-06-2020, Revised: 21-09-2020, Accepted: 28-09-2020)

\begin{abstract}
A study was conducted to assess the status of soil organic carbon stocks under selected plantation and altered and natural ecosystems in southern Karnataka. Seven locations were identified for the study following the agro-climatic variability. The sites identified were Brahmavara in Udupi (coastal zone), Balehonnur in Chikkamagalur (hilly zone), Madnur and Salegrama in Hassan (northern and southern transitional zone), Alburu in Tumkur (eastern and southern dry zone), Babbur and Javagamatur in Chitradurga (central dry zone). In each of these zones, natural forest ecosystems were assessed in comparison to the plantation-based ecosystems to understand the changes in soil development with emphasis to soil organic carbon (SOC) stocks. The SOC stocks at the surface varied from 1.24 to $6.44 \mathrm{~kg} \mathrm{~m}^{-3}$ in forests and from 1.53 to $6.51 \mathrm{~kg} \mathrm{~m}^{-3}$ in different plantation ecosystems. It was found from the study that SOC stocks followed the order hilly zone (per-humid climate) $>$ coastal zone (hot humid climate) $>$ eastern and southern dry zone (moist semi-arid climate) $>$ northern and southern transitional zone (dry sub-humid climate) $>$ central dry zone (dry semi-arid climate). The soils belonged to the order Ultisols and Alfisols. The major taxa of the soils identified at sub-group level of soil taxonomy are Rhodic Kandiustults, Typic Plinthohumults, Ustic Haplohumults, Typic Rhodustalfs, Rhodic Paleustalfs, Kandic Paleustalfs and Typic Haplustalfs.
\end{abstract}

Keywords: Characterization, plantation and forest ecosystems, soil classification, soil organic carbon stocks, southern Karnataka

\section{Introduction}

Soil is generally regarded as the greatest heritage of humankind and one of the world's valuable natural resources (Hillel, 1991). In the $21^{\text {st }}$ century, humankind faces a series of concerns, which are intimately linked to soils such as overpopulation and food shortage, degradation of agricultural land, air and water pollution, loss of biodiversity, genetically modified organisms, accumulation of greenhouse gases (GHG) and climate change. Carbon dioxide $\left(\mathrm{CO}_{2}\right)$ is the most dominant $\mathrm{GHG}$, followed by methane $\left(\mathrm{CH}_{4}\right)$ and nitrous oxide $\left(\mathrm{N}_{2} \mathrm{O}\right) . \mathrm{CO}_{2}$ accounts for about 50 per cent of the warming effect of all climate-impact gases (IPCC, 2001). There are several ways through which $\mathrm{CO}_{2}$ reaches the atmosphere, which could be by combustion of fossil fuels, or from solid wastes, agricultural and forestry activities, deforestation, and other land-use changes (Lal et al., 1997) or as a result of certain chemical reactions. Concentrations of GHGs especially $\mathrm{CO}_{2}$ in the atmosphere have increased by about 30 per cent over the last two centuries (IPCC, 2001) and the half of the rise has happened in the last three decades (www.ucusa.org). The global average temperature has risen by 0.2 to $0.6{ }^{\circ} \mathrm{C}$ during the twentieth century and rise in sea levels by about $15-20 \mathrm{~cm}$. If no action is taken to reduce GHG emissions, an increase in global warming of 1.4 to $5.8^{\circ} \mathrm{C}$ over 1990 level is projected to occur by 2100 and sea level rise by 9 to $88 \mathrm{~cm}$, which can inundate many coastal cities and intensive agriculture areas.

*Corresponding Author: anilsoils@yahoo.co.in 
Carbon sinks play an important role in the global carbon cycle to reduce the accumulation of GHGs in the atmosphere by increasing soil $\mathrm{C}$ sequestration and storage. Carbon sequestration is defined as the capture and long term storage of the carbon that would otherwise be emitted to or remain in the atmosphere. This helps in keeping the carbon emissions under control by sequestering them before reaching the atmosphere by capturing and diverting them to be stored in soil (Jain et al., 2012). Mean annual rainfall, tillage, the period of canopy cover, available water capacity (AWC), silt and clays have pronounced effects on carbon dynamics. Many studies reported that land use changes to a cultivated land decrease soil C storage (Houghton et al., 1999) because of the release of more $\mathrm{CO}_{2}$ to the atmosphere (Solomon et al., 2002). A periodical assessment of carbon stock is required to understand the effects of changes in land use on soil carbon storage. Thus, these data would help in refining national and global carbon stocks under the influence of changing land use and management scenario. Hence, this study was carried out in the selected locations in southern Karnataka based on the agro-climatic variability. Karnataka is located in the southwestern part of the Deccan peninsular India. It lies between $11^{\circ}$ to $18^{\circ} \mathrm{N}$ latitude and $74^{\circ}$ to $78^{\circ} \mathrm{E}$ longitude with a geographical area of 1.91 lakh square kilometers. It experiences a wide variety of geological climate, vegetation and physiographic conditions. As a result, the soils of Karnataka are highly diverse and variable depending upon their geographical conditions. The northern part of the state is dominated by shallow to deep black soils. The southern part of the state is dominated by red sandy to red loamy soil.

In contrast, heavy rainfall regions comprising the Western Ghats and the coastal districts are dominated by laterite and coastal alluvial soils. With these varied agro-climatic conditions and diverse soil types, the state is suitable for cultivation of varied crops. But the level of organic $\mathrm{C}$ in a given soil at any specific time depends on complex interactions of climate, soil physical, chemical and biological processes, vegetation and land use. They have a greater influence on $\mathrm{C}$ storage and play an important role in carbon sequestration in soil.

\section{Material and methods}

\section{Study area}

The study was undertaken in different agroclimatic zones of southern Karnataka narrowed to 5 zones covering seven locations with a larger area. The study locations were identified by using toposheets and LISS-III satellite data (Fig. 1). This includes Brahmavara in Udupi (coastal zone), Balehonnur in Chikkamagalur (hilly zone), Madnur and Salegrama in Hassan (northern and southern transitional zone), Alburu, Tiptur in Tumkur (eastern and southern dry zone), Babbur and Javagamatur, Hiriyur in Chitradurga (central dry zone). Profile studies were carried out in different natural and altered land-use systems, such as cashew plantation and semi-evergreen forest in Brahmavara, coffee plantation and evergreen forest in Balehonnur, coconut + field crops and mixed forest, fully stocked with less canopy and less ground cover in Hassan, arecanut and eucalyptus, moist scrub forest with thin canopy and low ground cover in Tiptur, coconut + red gram and Hiriyur eucalyptus, dry scrub forest with thinly populated and low ground cover in Hiriyur. In the study area, climate ranged from hot humid to per-humid in the coastal and the hilly zone to dry semi-arid climate in the plateau zone.

\section{Field study}

Soil profiles were opened in the selected locations and studied in detail for all their physical and morphological characteristics. The soil and site characteristics were recorded for all profiles sites as per guidelines given in USDA soil survey manual (Soil survey staff, 2010). Horizon-wise samples were collected for laboratory analysis. Soils were grouped based on identification characteristics and classified following USDA soil classification system.

\section{Laboratory analysis}

The soil samples collected horizon wise were air-dried under the shade, powdered and sieved using $2 \mathrm{~mm}$ sieve. Particle size analysis was carried out by International pipette method (Piper, 1966). Soil organic carbon was estimated by Walkley and Black (1934) method. Bulk density was determined for the samples collected from each horizon using a core sampler method. Soil samples from the core 
were dried at $105{ }^{\circ} \mathrm{C}$ for 24 hours and cooled in desiccators. Weight of air dried sample was recorded. The volume of the core was measured (Jackson, 1973). The $\mathrm{pH}$ and electrical conductivity were measured in 1:2.5 soil-water suspensions (Jackson, 1973). Available nitrogen was estimated by alkaline permanganate method (Subbiah and Asija, 1956).

\section{Soil organic carbon (SOC) stocks estimation}

For each of the soil profile, SOC stocks were calculated by summing the stocks of different layers in the proportion of their occurrence within the reference thickness. The total organic carbon stock in $\mathrm{kg} \mathrm{m}^{-3}$ soil for each pedon was estimated using the general equation presented below (Grossman et al., 2001).

$\mathrm{SOC}=\frac{\mathrm{L}_{1} \times \operatorname{SOCP}_{1} \times \mathrm{xp} 33_{1}\left(\frac{1-\mathrm{c}>2_{2}}{100}\right)+\mathrm{L}_{2} \mathrm{xSOCP}{ }_{1} \times \mathrm{xp} 33_{2}\left(\frac{1-\mathrm{v}>2_{2}}{100}\right)+\ldots}{10}$

Where $\mathrm{SOC}=$ soil organic carbon in $\mathrm{kg} \mathrm{m}^{-3}$

SOCP $=$ soil organic carbon per cent

$\mathrm{L}=$ thickness of the layer in $\mathrm{cm}$ (if only surface $15 \mathrm{~cm} ; \mathrm{L}_{1}=15 \mathrm{~cm}$; ignore $\left.\mathrm{L}_{2}, \mathrm{~L}_{3} \ldots\right)$.

$\rho=$ bulk density (oven dry)

$\mathrm{V}>2=$ volume per cent of $>2 \mathrm{~mm}$ (gravel)

The SOC stocks were calculated for $0-30 \mathrm{~cm}$ and $100 \mathrm{~cm}$ by summing the stocks of different layers in the proportion of their occurrence within this reference thickness by depth-weighted average.

\section{Results and discussion}

\section{Soils of the agro-climatic zones}

Soils of coastal and hilly zones belong to the order Ultisols and soils of the other agro-climatic zones belong to the order Alfisols (Table 1). The major taxa of the soils identified at sub-group level of soil taxonomy are Rhodic Kandiustults, Typic Plinthohumults, Ustic Haplohumults, Typic Rhodustalfs, Rhodic Paleustalfs, Kandic Paleustalfs and Typic Haplustalfs. Soils of Hiriyur were moderately shallow, and rest were deep to very deep, red, well-drained and appreciable amount of gravels were observed in all the pedons. The soil texture varied from sandy clay loam to sandy clay and clay
(Table 2). Textural variations are mainly associated with the type of parent material, degree of weathering, topography and time and a similar result was reported by Sitanggang et al. (2006).

\section{Selected properties of the soils}

Soil reaction varied from very strongly acidic to moderately acidic in Balehonnur and Brahmavara, moderately acidic to neutral in Hassan and Tiptur, neutral to moderately alkaline in Hiriyur (Table 2). Bulk density of soil varied from 0.86 to $1.86 \mathrm{Mg} \mathrm{m}^{-3}$ in the surface. In all the profiles, bulk density increased with depth. In Brahmavara cashew plantations and Balehonnur coffee plantations, a decrease in clay content down the soil profile was observed. In Hassan forest and Tiptur arecanut plantations, an irregular trend in clay distribution in the soil profile was observed. In Brahmavara forest, Hassan coconut growing area, Tiptur forest, Hiriyur coconut + red gram growing area and forest area, the clay increase was high in the solum indicating advanced soil profile development. The sub-surface horizons exhibited higher clay content as compared to surface horizons due to the illuviation process occurring during soil development (Sharma et al., 2004).

\section{Soil organic carbon}

Soil organic carbon content in the surface of forest ecosystems varied from 0.20 per cent in the Eucalyptus dry scrub forest in Hiriyur to 2.03 per cent in the evergreen forest in Balehonnur (Table 2). The SOC content was higher in the surface due to the dense forest in Western Ghats and deposition of plant litter along with the alluvium (Badrinath et al., 1986). Among all, Balehonnur (2.02\%) and Brahmavara soils $(1.75 \%)$ recorded comparatively higher organic carbon content in the surface mainly due to higher biomass production and consequently higher amount of litter added by forest vegetation to the soil. However, coffee plantation and cashew plantations recorded higher SOC content of 2.28 and 2.11 per cent respectively in the surface than the forest ecosystems of the same area. Mixed forest in Hassan recorded higher organic carbon content $(1.73 \%)$ in its surface than coconut + field crop ecosystem, which recorded 0.85 per cent. However, the scrub forests in Tiptur and Hiriyur recorded lesser organic carbon content $(0.52$ and $0.20 \%$ respectively) 
Table 1. Major soils of agro-climatic zones of southern Karnataka

\begin{tabular}{|c|c|c|c|c|}
\hline $\begin{array}{l}\text { Agro-climatic } \\
\text { zones }\end{array}$ & $\begin{array}{c}\text { Land management } \\
\text { systems }\end{array}$ & Location & Topography & $\begin{array}{c}\text { USDA soil } \\
\text { classification }\end{array}$ \\
\hline \multirow[t]{2}{*}{ Coastal zone } & Cashew plantation & Brahmavara & Undulating & $\begin{array}{l}\text { Clayey-skeletal, kaolinitic, acid, } \\
\text { isohyperthermic family of Rhodic } \\
\text { Kandiustults }\end{array}$ \\
\hline & Semi-evergreen forest & Brahmavara & Undulating & $\begin{array}{l}\text { Fine-loamy, kaolinitic, acid, sub-active, } \\
\text { isohyperthermic family of Typic } \\
\text { Plinthohumults }\end{array}$ \\
\hline \multirow[t]{2}{*}{ Hilly zone } & Coffee plantation & Balehonnur & Undulating & $\begin{array}{l}\text { Fine-loamy, mixed, acid, semi-active, } \\
\text { isohyperthermic family of Ustic } \\
\text { Haplohumults }\end{array}$ \\
\hline & Evergreen Forest & Balehonnur & Rolling & $\begin{array}{l}\text { Fine-loamy, mixed, semi-active, } \\
\text { isohyperthermic family of Ustic } \\
\text { Haplohumults }\end{array}$ \\
\hline \multirow[t]{2}{*}{$\begin{array}{l}\text { Northern and } \\
\text { Southern } \\
\text { transitional zone }\end{array}$} & Coconut + field crop & Hassan & Nearly level & $\begin{array}{l}\text { Clayey-skeletal, mixed, semi-active } \\
\text { isohyperthermic family of Typic } \\
\text { Rhodustalfs }\end{array}$ \\
\hline & Mixed forest & Hassan & Undulating & $\begin{array}{l}\text { Loamy- skeletal, mixed, super-active, } \\
\text { isohyperthermic family of Typic } \\
\text { Rhodustalfs }\end{array}$ \\
\hline \multirow[t]{2}{*}{$\begin{array}{l}\text { Eastern and } \\
\text { southern dry zone }\end{array}$} & Arecanut plantation & Tiptur & Nearly level & $\begin{array}{l}\text { Fine, mixed, semi-active, } \\
\text { isohyperthermic family of Rhodic } \\
\text { Paleustalfs }\end{array}$ \\
\hline & $\begin{array}{l}\text { Eucalyptus with } \\
\text { mixed scrub forest }\end{array}$ & Tiptur & Undulating & $\begin{array}{l}\text { Fine, mixed, semi-active, } \\
\text { isohyperthermic family of Kandic } \\
\text { Paleustalfs }\end{array}$ \\
\hline \multirow[t]{2}{*}{ Central dry zone } & Coconut + red gram & Hiriyur & Undulating & $\begin{array}{l}\text { Loamy- skeletal, mixed, super-active, } \\
\text { isohyperthermic family of Typic } \\
\text { Rhodustalfs }\end{array}$ \\
\hline & $\begin{array}{l}\text { Eucalyptus dry } \\
\text { scrub forest }\end{array}$ & Hiriyur & Undulating & $\begin{array}{l}\text { Loamy-skeletal, mixed, super-active, } \\
\text { calcareous isohyperthermic family of } \\
\text { Typic Haplustalfs }\end{array}$ \\
\hline
\end{tabular}

than the altered ecosystems of arecanut plantations and coconut + red gram systems. The lower organic carbon status observed in Hiriyur is due to low organic matter deposition associated with poor biomass production and enhanced mineralization due to high temperature. Organic carbon content decreases with depth due to the decreasing root biomass with depth and lesser $\mathrm{C}$ accumulation at depth. The leaching environment existing in the area, coupled with very high rainfall of high intensity in the hilly and coastal zone and concentrated rainfall and porous nature of deep red gently sloping upland soils of plateau region also decreases organic carbon content with depth. These results are in agreement with Patil and Dasog (1999).

\section{SOC Stocks}

\section{Carbon stocks in different agro-climatic zones}

Out of five zones, the SOC values followed the order, hilly zone (per-humid climate) $>$ coastal zone (hot humid climate) $>$ eastern and southern dry zone (moist semi-arid climate) $>$ northern and southern transitional zone (dry sub-humid climate) $>$ central dry zone (dry-semi-arid climate) (Table 2 and Fig. 2). 
Bio-inoculants on growth and yield of betel vine

Table 2. Depth-wise distribution of selected soil properties

\begin{tabular}{|c|c|c|c|c|c|c|c|c|c|}
\hline \multirow{2}{*}{$\begin{array}{l}\text { Depth } \\
\text { (cm) }\end{array}$} & \multirow{2}{*}{$\begin{array}{l}\text { Clay } \\
(\%)\end{array}$} & \multirow{2}{*}{$\begin{array}{c}\text { Coarse } \\
\text { fragments } \\
(\%)\end{array}$} & \multirow{2}{*}{$\begin{array}{c}\text { Bulk } \\
\text { Density } \\
\left(\mathbf{M g ~ m}^{-3}\right)\end{array}$} & \multirow{2}{*}{$\begin{array}{c}\text { pH } \\
(1: 2.5)\end{array}$} & \multirow{2}{*}{$\begin{array}{c}E C \\
\left(\mathrm{dS} \mathrm{m}^{-1}\right)\end{array}$} & \multirow{2}{*}{$\begin{array}{l}\text { OC } \\
(\%)\end{array}$} & \multicolumn{2}{|c|}{$\operatorname{SOC}\left(\mathrm{kg} \mathrm{m}^{-3}\right)$} & \multirow{2}{*}{$\begin{array}{c}\text { Soil } \\
\text { texture }\end{array}$} \\
\hline & & & & & & & $0-30 \mathrm{~cm}$ & $0-150 \mathrm{~cm}$ & \\
\hline
\end{tabular}

1. Coastal zone: Brahmavara cashew plantation

\begin{tabular}{|c|c|c|c|c|c|c|c|c|}
\hline $0-12$ & 59.67 & 11.23 & 1.04 & 5.11 & 0.035 & 2.28 & 4.65 & 7.30 \\
\hline $12-37$ & 56.07 & 28.70 & 1.20 & 5.13 & 0.018 & 0.85 & & \\
\hline $37-57$ & 56.29 & 53.20 & 1.24 & 4.98 & 0.013 & 0.44 & & \\
\hline $57-94$ & 61.25 & 58.76 & 1.58 & 5.02 & 0.016 & 0.34 & & \\
\hline 94-131 & 56.35 & 67.13 & 1.59 & 5.04 & 0.015 & 0.14 & & \\
\hline $131-162$ & 44.54 & 70.15 & 1.51 & 4.82 & 0.014 & 0.16 & & \\
\hline $162-180$ & 37.42 & 70.10 & 1.63 & 4.98 & 0.012 & 0.06 & & \\
\hline
\end{tabular}

2. Coastal zone: Brahmavara forest

\begin{tabular}{|c|c|c|c|c|c|c|c|c|c|}
\hline $0-20$ & 28.71 & 11.21 & 1.19 & 5.65 & 0.01 & 1.75 & 5.37 & 10.16 & $\mathrm{scl}$ \\
\hline $20-48$ & 34.30 & 39.34 & 1.33 & 5.34 & 0.02 & 1.36 & & & vgscl \\
\hline $48-80$ & 30.66 & 44.45 & 1.56 & 5.09 & 0.02 & 0.56 & & & vgscl \\
\hline $80-110$ & 32.25 & 75.46 & ND & 5.13 & 0.01 & 0.32 & & & egscl \\
\hline $110-160$ & 29.13 & 79.23 & ND & 5.09 & 0.01 & 0.12 & & & egscl \\
\hline \multicolumn{10}{|c|}{ 3. Hilly zone: Balehonnur coffee plantation } \\
\hline $0-18$ & 33.45 & 6.34 & 0.86 & 5.15 & 0.00 & 2.11 & 6.51 & 10.56 & $\mathrm{scl}$ \\
\hline $18-35$ & 33.64 & 8.25 & 1.42 & 5.27 & 0.04 & 1.13 & & & $\mathrm{scl}$ \\
\hline $35-58$ & 35.88 & 15.65 & 1.21 & 5.25 & 0.03 & 0.54 & & & $\mathrm{scl}$ \\
\hline $58-89$ & 32.89 & 21.38 & 1.11 & 5.26 & 0.02 & 0.34 & & & gscl \\
\hline $89-123$ & 27.52 & 33.10 & 1.31 & 5.29 & 0.01 & 0.15 & & & gscl \\
\hline $123-151$ & 27.23 & 45.10 & 1.21 & 5.35 & 0.01 & 0.15 & & & vgcl \\
\hline
\end{tabular}

\section{Hilly zone: Balehonnur forest}

\begin{tabular}{|c|c|c|c|c|c|c|c|c|c|}
\hline $0-15$ & 31.87 & Nil & 1.09 & 6.36 & 0.10 & 2.03 & 6.44 & 11.97 & $\mathrm{scl}$ \\
\hline $15-31$ & 34.62 & 5.24 & 1.38 & 6.43 & 0.05 & 1.38 & & & $\mathrm{scl}$ \\
\hline $31-58$ & 37.44 & 33.45 & 1.46 & 6.41 & 0.03 & 0.83 & & & vgsc \\
\hline $58-79$ & 29.08 & 13.34 & 1.56 & 6.51 & 0.04 & 0.42 & & & $\mathrm{scl}$ \\
\hline $79-115$ & 29.29 & Nil & 1.68 & 6.55 & 0.03 & 0.07 & & & $\mathrm{scl}$ \\
\hline $115-151$ & 27.91 & Nil & 1.57 & 6.55 & 0.04 & 0.16 & & & $\mathrm{scl}$ \\
\hline \multicolumn{10}{|c|}{ 5. Northern and southern transitional zone: Hassan coconut+field crops } \\
\hline $0-20$ & 21.26 & 15.27 & 0.86 & 6.37 & 0.00 & 0.46 & 1.56 & 3.84 & $\mathrm{scl}$ \\
\hline $20-36$ & 35.14 & 42.34 & 1.39 & 6.47 & 0.07 & 0.56 & & & $\operatorname{vgscl}$ \\
\hline $36-90$ & 38.61 & 58.25 & 1.47 & 6.22 & 0.09 & 0.34 & & & $\operatorname{vgsc}$ \\
\hline 90-109 & 42.20 & 60.21 & 1.10 & 6.25 & 0.01 & 0.16 & & & egsc \\
\hline $109-129$ & 46.98 & 43.76 & 1.77 & 6.36 & 0.09 & 0.15 & & & vgsc \\
\hline $129-161$ & 30.06 & 38.56 & 1.76 & 6.24 & 0.10 & 0.07 & & & vgscl \\
\hline $161-180$ & 20.94 & 22.47 & 1.85 & 6.51 & 0.09 & 0.09 & & & gscl \\
\hline
\end{tabular}




\begin{tabular}{|c|c|c|c|c|c|c|c|c|c|}
\hline \multicolumn{10}{|c|}{ 6. Northern and southern transitional zone: Hassan forest } \\
\hline $0-16$ & 14.92 & 24.56 & 1.06 & 5.85 & 0.00 & 1.73 & 3.69 & 8.72 & gsl \\
\hline $16-41$ & 22.60 & 37.76 & 1.27 & 6.02 & 0.05 & 0.91 & & & vgscl \\
\hline $41-60$ & 12.17 & 32.48 & 1.37 & 6.51 & 0.05 & 0.56 & & & gls \\
\hline $60-107$ & 25.95 & 69.67 & 1.45 & 6.71 & 0.06 & 0.75 & & & egscl \\
\hline $107-151$ & 33.05 & 75.76 & 1.11 & 6.80 & 0.08 & 0.95 & & & egscl \\
\hline $151-200$ & 18.48 & 72.34 & 1.68 & 6.17 & 0.03 & 0.28 & & & egsl \\
\hline \multicolumn{10}{|c|}{ 7. Eastern and southern dry zone: Tiptur arecanut plantation } \\
\hline $0-20$ & 47.32 & 8.25 & 1.27 & 7.15 & 0.00 & 0.85 & 3.82 & 10.41 & $\mathrm{c}$ \\
\hline $20-31$ & 46.88 & 10.34 & 1.40 & 7.04 & 0.08 & 0.83 & & & $\mathrm{c}$ \\
\hline $31-50$ & 47.96 & 14.03 & 1.66 & 7.19 & 0.07 & 0.46 & & & $\mathrm{sc}$ \\
\hline $50-87$ & 42.86 & 19.80 & 1.77 & 6.91 & 0.06 & 0.42 & & & gsc \\
\hline $87-110$ & 41.76 & 30.49 & 1.77 & 7.05 & 0.07 & 0.34 & & & gsc \\
\hline $110-156$ & 37.20 & 45.42 & 1.87 & 6.96 & 0.07 & 0.42 & & & $\operatorname{vgsc}$ \\
\hline $156-185$ & 39.56 & 6.02 & 1.86 & 6.95 & 0.07 & 0.18 & & & $\mathrm{sc}$ \\
\hline \multicolumn{10}{|c|}{ 8. Eastern and southern dry zone: Tiptur forest } \\
\hline $0-20$ & 25.86 & 5.24 & 1.15 & 5.36 & 0.00 & 0.52 & 2.11 & 6.81 & $\mathrm{scl}$ \\
\hline $20-44$ & 31.57 & 6.89 & 1.36 & 5.87 & 0.05 & 0.56 & & & $\mathrm{scl}$ \\
\hline $44-78$ & 46.73 & 7.27 & 1.66 & 6.89 & 0.04 & 0.30 & & & $\mathrm{sc}$ \\
\hline $78-125$ & 50.01 & 32.78 & 1.45 & 6.27 & 0.07 & 0.28 & & & gsc \\
\hline $125-161$ & 33.94 & 56.38 & 1.78 & 6.46 & 0.08 & 0.07 & & & vgscl \\
\hline \multicolumn{10}{|c|}{ 9. Central dry zone: Hiriyur coconut+Red gram growing area } \\
\hline $0-15$ & 23.01 & 6.65 & 1.24 & 7.92 & 0.00 & 0.54 & 1.53 & 2.60 & $\mathrm{scl}$ \\
\hline $15-33$ & 37.15 & 53.25 & 1.11 & 8.05 & 0.08 & 0.42 & & & $\operatorname{vgsc}$ \\
\hline $33-50$ & 26.71 & 44.78 & 1.58 & 8.15 & 0.17 & 0.56 & & & vgscl \\
\hline $50-72$ & 22.01 & 81.11 & 1.68 & 8.17 & 0.16 & 0.16 & & & egscl \\
\hline \multicolumn{10}{|c|}{ 10. Central dry zone: Hiriyur forest area } \\
\hline $0-12$ & 18.95 & 19.24 & 1.86 & 6.80 & 0.00 & 0.20 & 1.24 & 1.81 & gsl \\
\hline $12-26$ & 22.87 & 31.12 & 1.12 & 6.90 & 0.08 & 0.58 & & & gscl \\
\hline $26-40$ & 22.76 & 55.45 & 1.28 & 7.50 & 0.13 & 0.44 & & & vgscl \\
\hline $40-68$ & 19.39 & 83.67 & 1.56 & 7.33 & 0.10 & 0.36 & & & egsl \\
\hline
\end{tabular}

Higher SOC values are a result of higher biomass or dry matter production owing to high rainfall and temperature, resulting in higher carbon accumulation. Low SOC values are due to low rainfall and higher temperature, resulting in faster decomposition, higher gravel content and erosion. Influence of climate on carbon stocks and land quality has been reported in coffee plantations of
Karnataka by Anil Kumar and Shalima Devi (2009) that the highest SOC stocks and land quality are observed in humid, moist sub-humid, followed by per-humid and dry sub-humid the least, owing to high thickness of organic carbon-rich surface horizon, low bulk density, good surface cover and high biomass production, mineralization and assimilation supported by high biological activity. 


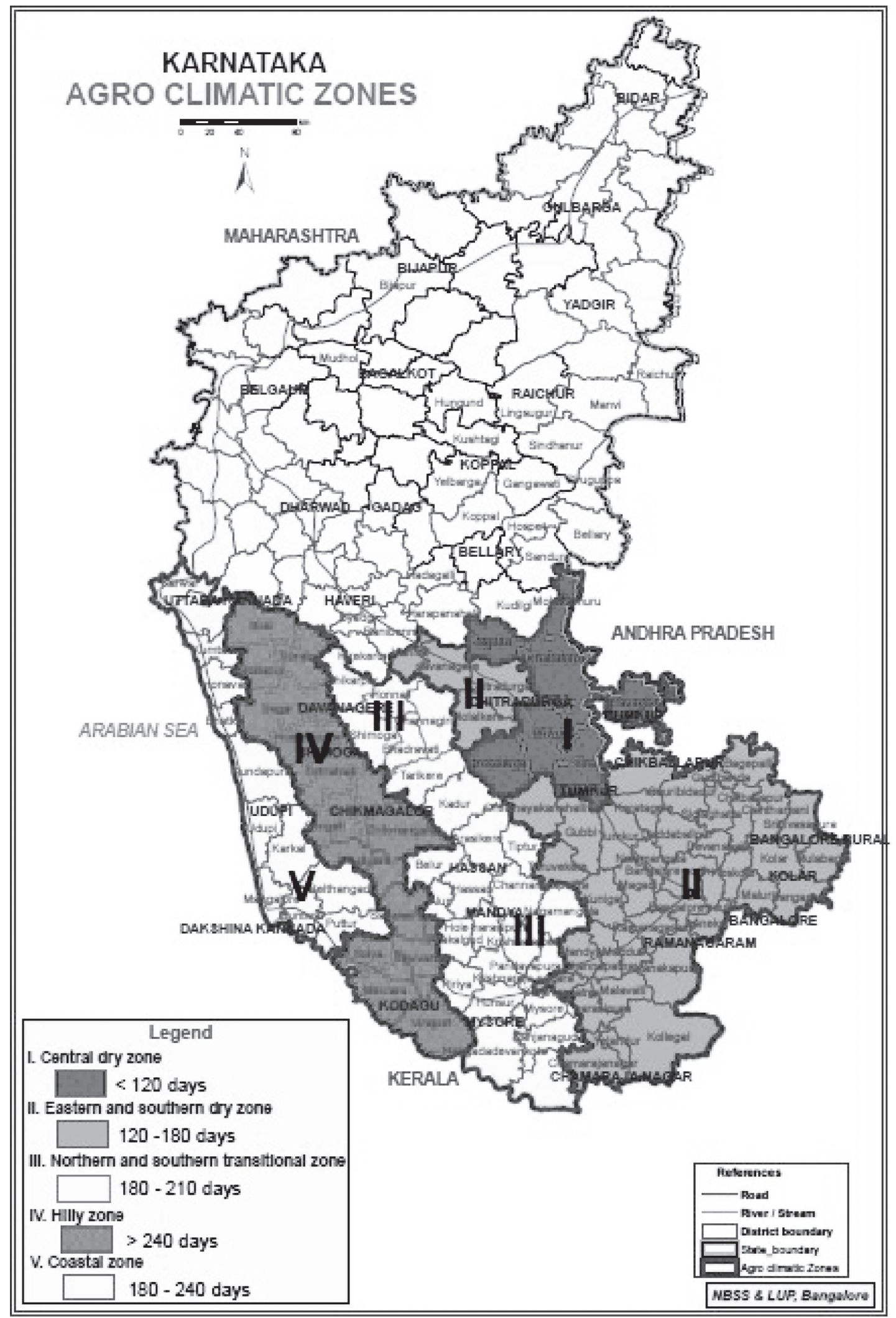

Fig. 1. Location map of study area with agro-climatic zones and LGP 

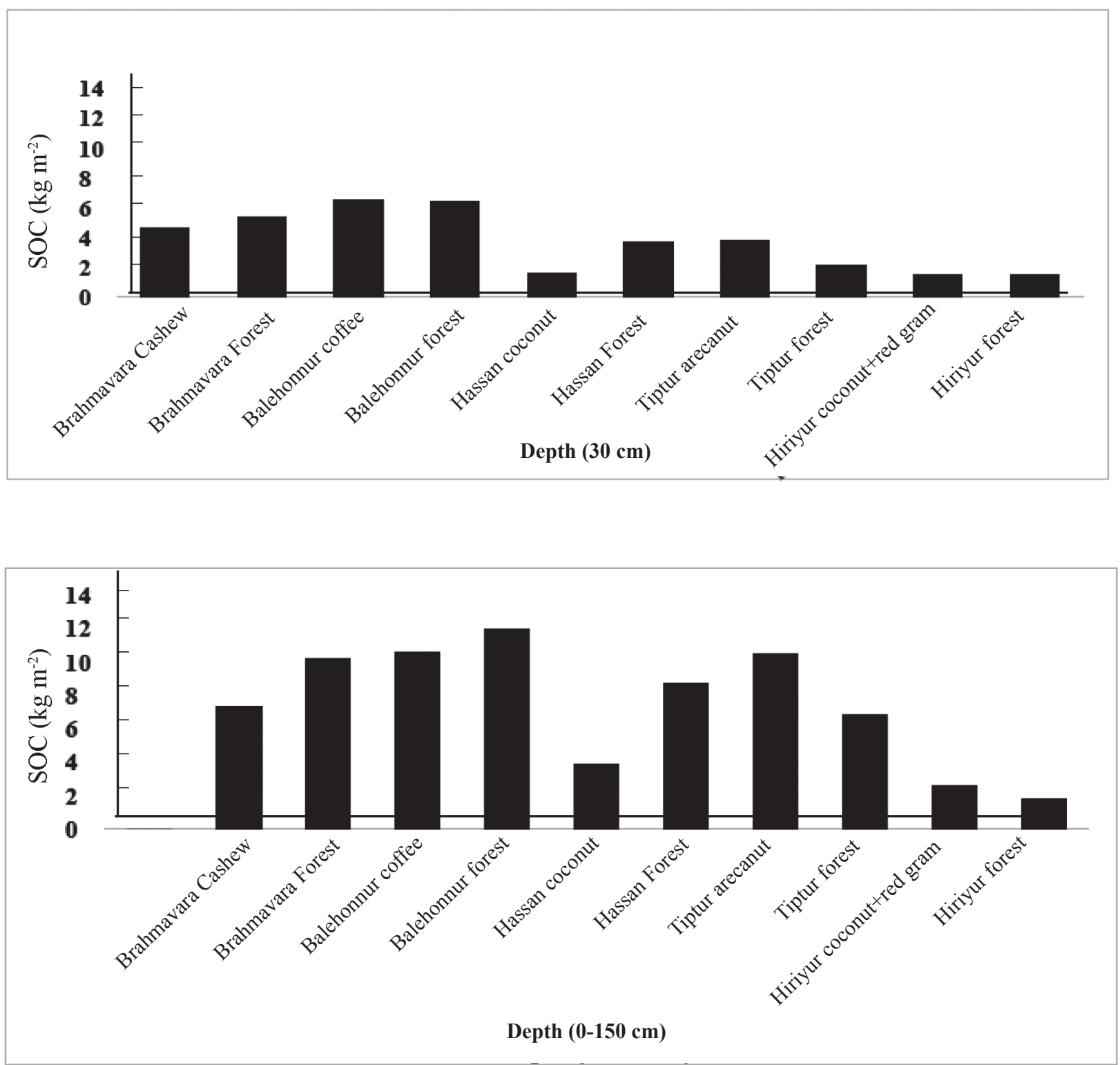

Fig. 2. Soil organic carbon (SOC) stocks at $0-30 \mathrm{~cm}$ and $0-150 \mathrm{~cm}$ depth

\section{Carbon stocks under different land-use systems}

Among different altered land-use systems studied, the surface $(0-30 \mathrm{~cm})$ soil organic carbon stock varied from $1.24 \mathrm{~kg} \mathrm{~m}^{-3}$ in the coconut + red gram system in Hiriyur to $6.51 \mathrm{~kg} \mathrm{~m}^{-2}$ in the coffee plantation in Balehonnur belonging to the Hilly zone. The surface $(0-30 \mathrm{~cm})$ soil organic carbon stock in the forest ecosystems varied from $1.24 \mathrm{~kg} \mathrm{~m}^{-3}$ in the eucalyptus dry scrub forest in Hiriyur to $6.44 \mathrm{~kg} \mathrm{~m}^{-3}$ in the evergreen forest in Balehonnur belonging to the Hilly zone. SOC stock for 0-150 $\mathrm{cm}$ also followed a similar trend (Table 2). The SOC values $(0-150 \mathrm{~cm})$ followed the order Balehonnur coffee $\left(10.56 \mathrm{~kg} \mathrm{~m}^{-3}\right)>$ Tiptur arecanut $\left(10.41 \mathrm{~kg} \mathrm{~m}^{-3}\right)$ $>$ Brahmavara cashew $\left(7.30 \mathrm{~kg} \mathrm{~m}^{-3}\right)>$ Hassan coconut + field crop $\left(3.84 \mathrm{~kg} \mathrm{~m}^{-3}\right)>$ Hiriyur coconut $+\operatorname{red} \operatorname{gram}\left(2.60 \mathrm{~kg} \mathrm{~m}^{-3}\right)$. This is due to high biomass production offered by cropping systems under the influence of climate with enhanced rhizosphere, mycorrhizal and biological activity (Srinivasan et al., 2019). The SOC stock at $0-150 \mathrm{~cm}$ also exhibited a 
similar trend. Among the natural systems studied, the SOC values $(0-150 \mathrm{~cm})$ followed the order Balehonnur humid tropical evergreen forest (11.97 $\left.\mathrm{kg} \mathrm{m}^{-3}\right)>$ Brahmavara semi ever-green forest $(10.16$ $\left.\mathrm{kg} \mathrm{m}^{-3}\right)>$ Hassan mixed forest, fully stocked with less canopy and less ground cover $\left(8.72 \mathrm{~kg} \mathrm{~m}^{-3}\right)>$ Tiptur eucalyptus, moist scrub forest with thin canopy and low ground cover $\left(6.81 \mathrm{~kg} \mathrm{~m}^{-3}\right)>$ Hiriyur eucalyptus, dry scrub forest with thinly populated and low ground cover $\left(1.81 \mathrm{~kg} \mathrm{~m}^{-3}\right)$. High canopy and ground cover decides the biomass production and fate of organic carbon favoured by climate for carbon sequestration with enhanced rhizosphere and mycorrhizal biological activity (Srinivasan et al., 2019). Forest with eucalyptus exhibited low SOC and SOC stocks due to allelopathic effect resulting in a reduction in biological activity, selective flora and fauna, more decomposition and removal of $\mathrm{C}$ from solum coined by Anil Kumar et al. (2015). The pedons with higher thickness of soil horizon, lower bulk density values and lower volume of gravel content recorded higher SOC values. These are the direct factors that affect soil organic carbon stocks (Pradeep, 2019). Soil reaction, texture, structure and roots and pores constitute the indirect factors that contribute to soil carbon storage in soil.

\section{Conclusion}

SOC stocks $\left(\mathrm{kg} \mathrm{m}^{-3}\right)$ values varied among different agro-climatic zones of southern Karnataka and different land-use systems. SOC stock values were higher in the hilly zone than other agroclimatic zones of southern Karnataka, and SOC stock was higher in natural forest systems compared to altered plantation systems. Evergreen forest systems were found to have high organic carbon stock in soil when compared to cultivated lands. However, proper management system adopted in cultivated land can sequester more carbon as observed from the arecanut plantations in Tiptur of the southern and eastern dry zone of Karnataka. The coffee and cashew plantations were found to be nearly on par with that of forest ecosystems in terms of carbon storage. High SOC stock is an indication of better soil and land quality, and if lands are better managed, it could yield the maximum in a sustainable manner.

\section{References}

Anil Kumar, K.S. and Shalima Devi, G.M. 2009. Soil organic carbon stocks as a land quality indicator under the coffee land use system in Karnataka. Journal of Coffee Research 37: $43-65$.

Anil Kumar, K.S., Lalitha, M., Kalaiselvi, B., Siddaram Patil, Nair, K.M. and Sujatha, K., 2015. Soil organic carbon stocks: A potential land quality indicator for soils of Western Karnataka. Agropedology 25: 161-168.

Badrinath, M.S., Krishnan, A.M., Patil, B.N., Kenchaiah, K. and Balakrishna Rao, K. 1986. Fertility status of some typical soils of coastal Karnataka. Journal of the Indian Society of Soil Science 34: 436-438.

Grossman, R.B., Harms, D.S., Kinngsbury, D.F., Shaw, R.K. and Jenkins A.B. 2001. Assessment of soil organic carbon using the U.S Soil Survey. In: Assessment Methods for Soil Carbon. (Eds.) Lal, R., Kimble J., Follet, R.F. and Stewart, B.A., CRC press, Boca Raton pp. 87-102.

Hillel, D.J. 1991. Out of the Earth: Civilization and the Life of the Soil, Maxwell Macmillan Intern., New York.

Houghton, R.A., Hacker, J.L. and Lawrence, K.T. 1999. The US Carbon Budget: Contributions from land use change, Science 285: 574-578. doi:10.1126/science. 285.5427.574.

Jackson, M.L. 1973. Soil Chemical Analysis. Prentice Hall of India (Pvt.) Ltd., New Delhi.

Jain, R., Urban, L., Balbach, H. and Webb, M.D. 2012. Chapter Thirteen: Contemporary issues in environmental assessment. In: Handbook of Environmental Engineering Assessment. 361-447. https://doi.org/10.1016/B978-012-388444-2.00013-0.

Lal, R., Kimble, M. and Follett, B., 1997. Land use and soil C pools in terrestrial ecosystems. In: Management of Carbon Sequestration in Soil, CRC Press, Boca Raton pp. 1-9.

IPCC, 2001. The Third Governmental Panel on Climate Change Assessment Report, 2001. Climate Change 2001: Impacts, Adaptations and Vulnerability. Report of Working Group II, Boca Raton.

Patil, P.L. and Dasog, G.S. 1999. Genesis and classification of ferruginous soils in Western Ghats and Coastal region of North Karnataka. Agropedology 9: 1-15.

Piper, C.S. 1966. Soil and Plant Analysis. Hans Publisher, Bombay.

Pradeep, 2019. Assessment of carbon sequestration potential of soils under different agro-climatic zones of southern Karnataka. M.Sc. Ag. Thesis, UAS, Bangalore 163p.

Sharma, S.S., Totawat, K.L. and Shyampura, R.L. 2004. Characterisation and classification of salt-affected soils of southern Rajasthan. Journal of the Indian Society of Soil Science 52: 209-213. 
Sitanggang, M., Rao, Y.S., Nayan Ahmed and Mahapatra, S.K. 2006. Characterization and classification of soils in watershed area of Shikohpur, Gurgaon district, Haryana. Journal of the Indian Society of Soil Science 54: 106-110.

Soil Survey Staff. 2010. Keys to Soil Taxonomy, Eleventh Edition. U.S.D.A.: Washington, D.C.

Solomon, D., Fritzsche, F., Lehmann, J., Tekalign, M. and Zech, W. 2002. Soil organic matter dynamics in the subhumid agro-ecosystems of the Ethiopian Highlands: Evidence from Natural ${ }^{13} \mathrm{C}$ abundance and particle-size fractionation. Soil Science Society of America Journal 66(3): 969-978. doi:10.2136/sssaj2002.0969.
Srinivasan, R., Natarajan, A., Anil Kumar, K.S. and Lalitha, M., 2019, Carbon stocks in major cashew growing soils of coastal Karnataka, India. Journal of Plantation Crops. 47: 55-61.

Subbiah, B. and Asija, C.L. 1956. A rapid procedure for the estimation of available nitrogen in soils. Current Science 25: 270-280.

Walkley, A. and Black. C.A. 1934. Estimation of organic carbon by chromic acid titration method. Soil Science 37: 29-38.

www.ucusa.org: The Planets' temperature is rising: Report published, 2016. 